\title{
DOES A GRAPH-INTENSIVE ECONOMICS CURRICULUM PROMOTE EPISTEMOLOGICAL ACCESS TO ECONOMIC THEORY?
}

\author{
J. Marire \\ Economics Department \\ Rhodes University \\ Grahamstown, South Africa \\ e-mail: juniours@gmail.com
}

\section{ABSTRACT}

The article evaluates whether graph-intensive pedagogic and assessment practices in introductory economics, promote student learning. It evaluates the role of instructor-supplied graphs in the correct application and interpretation of graphs. Using simple linear and panel regressions on student assessment data for graph-based multiple choice questions and descriptive analysis based on written student answers, the article finds that graph-intensive pedagogic and assessment practices hinder student learning and that there are gender and epistemological biases associated with them. While instructor-supplied graphic illustrations offer a solution, findings suggest a contrary adverse effect. Such supplementary materials are necessary but not sufficient in promoting deep learning. Combined with negative marking, graph dominated assessment practices encourage students to avoid answering graph-based questions, which undermines their performance.

Keywords: graph-based MCQs, epistemological access, introductory economics

JEL Codes: 121, 123

\section{GLOBAL CONTEXTUAL SHIFTS IN ECONOMICS CURRICULUM}

The rich plurality of voices that punctuates economic theory in history of economic thought has paled into insignificance with the ascendancy of mathematical formalism in economics. This has culminated in frustration amongst students of economics in the most recent years (since the global financial crisis, 2008/2009) because of their disappointment with the dismal failure of economists, for example, to predict major economic crises despite use of extremely complex economic models presumed to have high predictive value (The Economist 2013).

In response, the Institute of New Economic Thinking (INET) was recently established with the goal of rethinking and redressing the narrowness, the dryness/formalism, the acontextuality, the lack of reflexivity and the unidisciplinarity of economics curriculum as currently taught as well as the real world data-poverty in the teaching of economics, the weak application in economics curriculum and the failure to equip students with relevant skills for the world of work (Coyle 2012; Coyle 2014; Inman 2013a; Inman 2013b; The Economist 2013). 
Global student activism has internationalised curriculum issues in economics, with the University of Manchester Post-Crash Economics Society (UMPES) (2014) and the Cambridge Society for Economic Pluralism (CSEP) taking a leading role.

The narrowness of the economics curriculum seems to be methodologically driven at core. Indeed, students feel that it is formalism that 'preclude[s] the development of meaningful critical thinking and evaluation' (UMPES 2014, 9). Inman (2013b) rightly points out that 'the economics profession went astray because economists, as a group, mistook beauty, clad in impressive-looking mathematics, for truth'. The failure of economics curriculum to ground learners into the art of developing complex explanations of social reality is what is being criticised here.

A recent study in South Africa has come to the conclusion that while first year economics curriculum is complex, its complexity has been lost because of a reductionist approach to teaching it, which fails to equip learners with critical thinking and information literacy skills (Ojo and Jeannin 2016). As Ojo and Jeannin (2016) put it, 'the ultimate goal of teaching economics: [is] to equip students with the autonomy to understand economic policies and become thoughtful economic actors'. The thread running through the critiques seems to suggest that the teaching of economics has focused not on equipping students with skills of meaningmaking and sense-making but with answer production and reproduction of formal logical procedures, such as graphic and mathematical representation of theory, without enhancing the slightest understanding of what the procedures entail and what the weaknesses of the procedures are.

The article is motivated by concerns based on my lived experiences as a teacher of, and assessor of learners' work in, first year economics at a South African University. I have encountered several, not few, disconcerting cases in introductory economics and third year economics courses alike. Students struggle with graphs and often draw some of the weirdest graphs in examinations. Given the time I spent deconstructing the graphs with learners, I have been left perplexed like Isaiah, the prophet, in the Song of the Vineyard:

My well-beloved had a vineyard on a fertile hill. He dug it all around, removed its stones, [a]nd planted it with the choicest vine ... He expected it to produce good grapes, [b]ut it produced only worthless ones. What more was there to do for My vineyard that I have not done in it? Why, when I expected it to produce good grapes did it produce worthless ones? (New American Standard Bible, Isaiah 5 verses $1-4$, emphasis mine).

The farmer removed stones (learning/epistemic obstacles), dug the hill (for vines to have deep roots (students to engage with economics deeply)) and only the best of vines were planted (good 
students, though there is the problem of underprepared new comers to university in the South African context (Snowball 2014)), yet the result was the least expected (wild grapes, weird graphs). Consequently, I test the hypotheses that

- Hypothesis 1: Graph-intensive teaching pedagogies in economics hinder student learning (Cohn and Cohn 1994; Cohn et al. 2001; Cohn et al. 2004; Zetland, Russo and Yavapolkul 2010; the papers are reviewed below)

- $\quad$ Corollary hypothesis 1a: Students cannot interpret already given correct graphs

- $\quad$ Corollary hypothesis 1b: Students who cannot interpret graphs already reproduced for them can much less personally reproduce and apply graphs correctly

- Corollary hypothesis 1c: Instructor-supplied supplementary materials that decode the graphs are only a necessary but not sufficient condition in promoting deep student learning (somewhat contrary to Cohn and Cohn (1994) as discussed below).

The article is organised as follows. I first problematise graph based pedagogies, followed by an outline of the method of analysis and data sources, which is also followed by the presentation of findings and discussion and conclusions.

\section{PROBLEMATISING GRAPH-BASED PEDAGOGIES}

A debate, since the 1980s, has been unfolding among economic educationists about the degree to which graph-intensive introductory economics curriculum and pedagogy facilitate rich learning experiences (Becker 2001; Becker 2003; Cohn and Cohn 1994; Cohn et al. 2001; Cohn et al. 2004; Harter, Becker and Watts 1999; Kourilsky and Wittrock 1987; Zetland, Russo and Yavapolkul 2010). Research into the promotion of effective teaching and learning of economics in schools, colleges and universities has been unfolding. Becker (2001, not paged) points out that enrolment declines in the economics major since the 1990s were on account of economic pedagogies and that 'unless economists abandon their dogmatic, inflexible, preachy teaching style, students will probably continue to vote with their feet'. The greater focus has to be on how to 'deal with students' uneasiness about taking economics courses (Becker 2001, not paged).

There were, and are, still concerns that the teaching of economics in a graph-intensive mode might be a hindrance to epistemological access to economic theory for learners (e.g. Zetland et al. 2010). Graphs are the workhorse in the teaching of economics, especially introductory economics and the assumption, as Cohn and Cohn $(1994,197)$ state it, is that 
'students are capable of reproducing graphs drawn on the board or shown on an overhead projector'. As Becker and Watts $(1996,452)$ and Watts and Becker $(2008,284)$ consistently found in national surveys on the teaching of economics in the USA, graphs are still considered by lecturers as 'extremely important' in introductory economics. However, the overarching concern among economic educationists is that 'graphs may not increase student learning in principles courses’ (Watts and Becker 2008, 284).

Innumerable luminaries of economics, in the distant past, wrote analytically and conceptually rich books with much text and few tabular illustrations and much more rarely, graphs. Consider the number of graphs found in some introductory economics textbooks: Parkin et al. (2013) 467 graphs, Mankiw (1997) 197 graphs, and the South African textbook Janse van Rensburg et al. (2015) 150 graphs. As a rough estimation, most first year economics textbooks have 20 to 30 chapters. If we take the average number of graphs per chapter, we are likely to get a range of 5 to 10 graphs per chapter. The average number of graphs per chapter in a modern economics textbook is equivalent to the overall number of graphs in an entire economics textbook of the early $20^{\text {th }}$ century e.g. Taussig's voluminous 1924 edition of principles of economics, which has only 12 graphs. If economics can be taught in a non-mathematical way, why do graphs, which are in any case a pictorial mathematical representation, still dominant in the teaching of economics? When students struggle with English as a language of instruction across disciplines in African universities for example, recourse, sometimes, is made to multilingual solutions. When graphs are the matter, however, one is likely to encounter the reaction, 'It is difficult to teach anything in economics without graphs'.

In an influential paper, Kourilsky and Wittrock (1987) argued that it was the sequencing of verbal and graphic modes of instruction that really influenced whether learners would experience rich learning processes in economics. Based on an experimental study, they tested and ranked three modes of instruction in principles of economics in the following descending order: 'verbal then graphs', 'graphs then verbal' and 'verbal only'. Students who were exposed to richer verbal instruction followed by graphic synthesis of the principles already established during verbal instruction proved to have the most excellent understanding of economics. Students who were exposed to graphic instruction first, and then verbal explanation of the graph to deduce principles, experienced constraints to epistemological access, but they still fared better than those who were exposed to verbal instruction only.

Cohn and Cohn (1994), Cohn et al. (2001) and Cohn et al. (2004) conducted pedagogic experiments by teaching the same economics content 'with graphs' and 'without graphs' by dividing the class randomly into a 'verbal lecture with no graphs' group and 'a verbal lecture 
with graphs' group. In their 1995 experiment, they 'found that gain scores for students in the graphs lecture were actually lower than for those in the no-graphs lecture' (Cohn et al. 2001, 305). In the 1997 experiment, they found no statistically significant difference in the performance of students in both groups. Similarly, in both the 1995 and the 1997 experiment, they found that students who had high mathematics knowledge did not statistically significantly gain more than those who had low mathematical knowledge in the 'with graphs' economics lecture. These findings cast a glimmer of light on the possibility of a curriculum of economics with minimum usage of graphs.

These studies suggested that it was not just the correct presentation of economic theory graphically in the lecture that mattered, but also that the students had the correct graphs in their notes. When they used student notebooks as data for analysis they found that some students had entirely wrong graphs in their notebooks (Cohn and Cohn 1994). This led them to conclude that instructor-supplied graphs could assist struggling learners to reproduce correct graphs in the examination. Cohn and Cohn’s (1994), Cohn et al.’s (2001) and Cohn et al.’s (2004) results suggest that graphs have some pedagogical value, but on the main many graphic representations serve to confuse students. The pedagogic path dependence on graphic representations seems, as Cohn et al. (2001, 309) argue, to be on grounds that 'graphs might make the task of communicating economic concepts to the students easier for the instructor'. This is the essence of instructor-centred teaching processes.

In a related study, Cohn et al. (c.2002) found gender-bias against both white and nonwhite females in a graphs dominated teaching, learning and assessment environment. A very concerning finding, which has grave implications for epistemological access to economic theory, was that 'students expressing difficulty with graphs perform[ed] significantly worse than others' (Cohn et al. c.2002, 606).

As the debate continues to evolve, research is showing that the matter is not as straightforward as Kourilsky and Wittrock's (1987) influential hypothesis that it is the sequencing of graphic and verbal instruction that really matters. Zetland et al. $(2010,123)$ argue that the problem is more intrinsic to economic theory, at least in the way it is presented: it is 'naturally inverted'. All major theoretical building blocks present concepts in the inverse mode e.g. inverse demand function and marginal utility, among others. The inversion, for example of demand functions and curves, hinders epistemological access for students on three grounds: (1) it contradicts mathematical convention because a dependent variable (quantity demanded) is put on the horizontal axis and an explanatory variable (price) on the vertical axis; (2) students struggle with the transition from the direct algebraic demand function to the inverse graphic 
mode; and (3) students, unlike their teachers, might largely fail to realize that this inversion serves a larger purpose of integrating economic theory across several theorised domains in economics.

Zetland et al. (2010), exploring the question of whether representations of economic theory in the homogenous representation form (direct-direct or inverse-inverse) made students understand economics better than the canonical approach in economics textbooks, a heterogeneous representation form (direct-inverse), found that the inversion inherent in economic theory is a major hindrance to the learning of economic theory. They experimented with students who were learning economics for the first time up to those who were doing honours in economics. They exposed students to three modes of presenting demand theory: direct algebraic demand function accompanied with an inverse demand curve (direct-inverse, which is the norm in economics textbooks), inverse algebraic demand function accompanied with an inverse demand curve (inverse-inverse), and finally, direct algebraic demand function accompanied with a direct demand curve (direct-direct, which is the commonsensical experience of students when they think economics). They found that students did better in the homogeneous presentation of demand (inverse-inverse and direct-direct modes) and did worse with the conventional heterogeneous (direct-inverse) representation. Even in the homogeneous presentation, they found that students did a lot better with the direct-direct than with the inverseinverse presentation mode.

Zetland et al.'s (2010) findings, in terms of epistemological access to economic theory, are sobering because students who had spent a couple of years studying economics were still found to be struggling with the inverted economic theory just as the new comers did. They arrived at a startling finding that

this performance gap does not disappear with exposure to economics. Students who had taken four or more economics classes ... still did worse on inverse demand questions, (Zetland et al. 2010, 123-124, emphasis mine).

This led them to reject the rhetoric that over time students would master the inverted economic theory and be proficient in explaining and applying it. The real problem, as they found in their interviews with professors of economics, was that professors loved the inverted presentation of economic concepts for reasons of disciplinary traditions and taste, especially because 'inverse demand has network externalities for students (taking later economics classes) and professors (teaching in a way that is compatible with their colleagues)' (Zetland et al. 2010, 125). This led to the indictment that 'few economists are willing to discard graphs altogether' (Zetland et al. 
2010, 125). This institutional path dependence in the teaching of economics received considerable attention and the typical conclusion was:

that the shunning of teaching innovations by economists ... and ... the refusal to use alternative teaching methods reflects an equilibrium in which teaching efficiency, if not effectiveness, has been achieved (Becker and Watts 1996, 452, emphasis mine).

This 'equilibrium' and the presumed 'efficiency' and 'effectiveness' are questionable since the deficits in understanding economics persist even into higher classes. Zetland et al. (2010, 128), however, boldly suggest that 'the cost of "flipping axes" is outweighed by the benefits to students (improved comprehension and manipulation skills) and professors (less student confusion)'.

Hall and Lawson $(2008,13)$ also point out that there is a diversity of learners in economics, some excelling 'with the graphical analysis presented in textbooks' so much so that they can 'forego the classroom experience entirely'. Another group experiences liberating learning when the lecturer 'flesh[es] out the material in the classroom lecture', while others 'need to apply the material presented in class a few times before the idea sinks in'. The conventional graphic mode of presenting economic theory, therefore, favours one type of learner and epistemologically discriminates the other two groups, who, supposedly, are the majority. When the curriculum process privileges pedagogic practices that utilise epistemologically inaccessible symbols and pictures, it is discriminatory and biased. I now turn to how I tested this epistemological bias in the teaching and assessment of economics and how it influences student access to economic theory.

\section{METHODS AND DATA}

Evaluating performance of students in graph-based MCQs assesses the aspect of comprehension via the ability to interpret given graphs. All graphs that came in our semester tests and the examination had already been encountered in print, audio or video supplementary learning materials. Introductory economics enrols an average of 630 students every year. Students come from various Faculties in the University, many of whom are doing economics for the first time. The sheer size of the class and venue and personnel constraints demand technology aided teaching pedagogies. It is in that context that I prepared videos of different lengths - some focusing on graph-based MCQs and written questions; on threshold concepts in economics, key tutorial questions and applications to media news items.

To be able to address the question of whether graphs hinder or facilitate the learning of 
economics, unlike all previous studies (e.g. Cohn and Cohn 1994; Cohn et al. 2001) that rely on cross sectional experimental designs and evaluate the student after one short experiment; I relied on semester long assessment data. This helped me to address the question of temporal intellectual development of students.

Access to student records was granted by the Registrar's Division. A sample varying from 564 to 578 was used in a class of 610,582 of whom wrote the introductory economics examination in June 2016. Those who were excluded in the final sample had not written test 2 or test 3. The introductory economics examination paper is made up of 50 MCQs, with 43.75 per cent weight, and written questions, with 26.25 per cent weight. Multiple choice questions that were based on graphs were identified. Using the student report generated for the MCQ component of the examination, the numbers of graph-based MCQs a learner answered and failed were recorded just as was the number of graph-based MCQs the student left unanswered.

A simple linear regression model using bootstrapping techniques, first of all, was estimated to explain the percentage of failed MCQs in test 2 (which had 18 graph-based MCQs), test 3 (8 graph-based questions) and the examination (which had 9 graph-based questions). The simple linear regression model that was estimated was:

$\%$ of graph based MCQs failed $_{i}=a_{0}+a_{1} \%$ of graph based MCQs not answered ${ }_{i}+$ $a_{2}$ matric eonomics mark $_{i}+a_{3}$ matric maths mark m $_{i}+a_{4}$ matric points ${ }_{i}+$

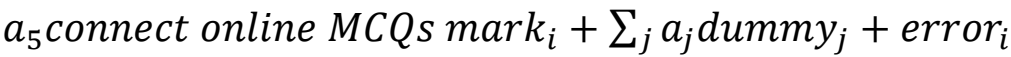

Where dummy, represents seven dummies, namely, female and degree type (bachelor of economics, bachelor of journalism, bachelor of science, bachelor of commerce, bachelor of social science, and bachelor of arts). The dummies took a value of one if a student fell into that category and zero otherwise. The base category for degree type was the foundation bachelor degrees across all the faculties. Equation (1) was also applied to a subsample of students who did mathematics, but not economics, and those that did economics and not mathematics. The rationale here was to assess the effects of prior maths and economics knowledge separately.

A priori, it was expected that $\mathrm{a}_{1}, \mathrm{a}_{2}, \mathrm{a}_{3}, \mathrm{a}_{4}, \mathrm{a}_{5}<0$. It was expected that the coefficients of bachelor of business science, bachelor of economics and bachelor of commerce would be negative and the other bachelors would have positive coefficients. The assumption was that students doing commerce-related degrees were likely to understand the content of economics better than the rest because they would have done economics-related subjects in high school.

As a second step, a panel regression for the percentage of failed MCQs was estimated 
based on the three assessments (test 2, test 3 and the examination). A Hausman specification test was conducted to decide between using the fixed effects and random effects regression models. The estimated model, following Wooldridge (2002), was specified as follows:

$\%$ of graph based MCQs failed $_{i t}=b_{0}+b_{1} \%$ of graph based MCQs not answered grt +

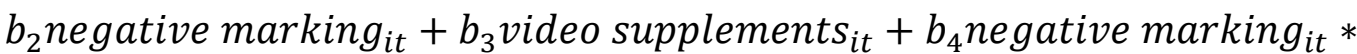
video supplements $s_{i t} * \%$ of graph based MCQs not answered ${ }_{i t}+$ error $_{i t}$

Negative marking is a dummy taking a value of one for a test or examination that employed negative marking, which the examination did, but the two tests did not. Video supplements is a dummy taking a value of one when videoed learning materials started to be produced and made available to students (and that was just after test 2 was written). These dummies were time variant unlike all the other learner attributes in equation (1).

A third step was to use graphs drawn by students in the written component of the examination. Since these graphs were faint and less readable even when photographed, I decided to replicate selected graphs as best as I could, using Microsoft word. Written questions drew upon tax incidence, indifference curve analysis for sin goods for which the Minister of Finance increased excise tax rates in the 2016 national budget speech for South Africa, production and cost theory and market structures. I selected the graphs based on (1) how weird they were (2) how common such graphs were in the student answers for the examination (3) the degree of epistemological blockage they signified.

\section{RESULTS AND ANALYSIS}

Table 1 reports student demographic and performance statistics on graph-based questions in the three waves of assessment for the introductory microeconomics course. Despite test 3 having the fewest graph-based MCQs and without negative marking, the average failure rate (50.3\%) was the highest (Table 1). The average failure rate for graph-based MCQs in the examination was 33.2 per cent.

Table 1 amplifies Cohn and Cohn's $(1994,197)$ argument that 'instructors assume that students are capable of reproducing graphs drawn on the board or shown on an overhead projector' in that students struggled to understand and interpret the graphs that had been reproduced for them rather than with the reproduction of the graphs. What is even more startling is that all graphs in test 3 and the examination came from test 2, with the exception of the indifference curve question. All of the questions in test 2 had detailed memo notes and a 
Table 1: Summary Performance Statistics for the Introductory Microeconomics Class

\begin{tabular}{|c|c|c|c|c|c|c|}
\hline & Median & Mean & $\begin{array}{l}\text { Standard } \\
\text { deviation }\end{array}$ & $\begin{array}{l}\text { Number of graph- } \\
\text { based MCQS }\end{array}$ & $N$ & Data type \\
\hline $\begin{array}{l}\% \text { of graph based MCQs } \\
\text { failed }\end{array}$ & $37.5 \%$ & $39.7 \%$ & 19.67 & 35 & 1703 & Panel \\
\hline $\begin{array}{l}\% \text { of graph based MCQs } \\
\text { not answered }\end{array}$ & $0 \%$ & $3.4 \%$ & 8.64 & 35 & 1703 & Panel \\
\hline $\begin{array}{l}\% \text { of graph based MCQs } \\
\text { failed test } 2\end{array}$ & $33.3 \%$ & $35.6 \%$ & 14.53 & 18 & 564 & $\begin{array}{l}\text { Cross } \\
\text { sectional }\end{array}$ \\
\hline $\begin{array}{l}\% \text { of graph based MCQs } \\
\text { failed test } 3\end{array}$ & $50 \%$ & $50.3 \%$ & 19.83 & 8 & 568 & $\begin{array}{l}\text { Cross } \\
\text { sectional }\end{array}$ \\
\hline $\begin{array}{l}\% \text { of graph based MCQs } \\
\text { failed exam }\end{array}$ & $33.3 \%$ & $33.2 \%$ & 19.69 & 9 & 578 & $\begin{array}{l}\text { Cross } \\
\text { sectional }\end{array}$ \\
\hline $\begin{array}{l}\% \text { of graph based MCQs } \\
\text { not answered test } 2\end{array}$ & $0 \%$ & $1.3 \%$ & 4.02 & 18 & 564 & $\begin{array}{l}\text { Cross } \\
\text { sectional }\end{array}$ \\
\hline $\begin{array}{l}\% \text { of graph based MCQs } \\
\text { not answered test3 }\end{array}$ & $0 \%$ & $0.7 \%$ & 4.54 & 8 & 568 & $\begin{array}{l}\text { Cross } \\
\text { sectional }\end{array}$ \\
\hline $\begin{array}{l}\% \text { of graph based MCQs } \\
\text { not answered exam }\end{array}$ & $0 \%$ & $8 \%$ & 12.34 & 9 & 578 & $\begin{array}{l}\text { Cross } \\
\text { sectional }\end{array}$ \\
\hline Matric maths mark & $59 \%$ & $59.4 \%$ & 11.62 & & 483 & $\begin{array}{l}\text { Cross } \\
\text { sectional }\end{array}$ \\
\hline Matric economics mark & $66 \%$ & $66 \%$ & 11.45 & & 151 & $\begin{array}{l}\text { Cross } \\
\text { sectional }\end{array}$ \\
\hline Matric points & 39.8 & 39.6 & 5.16 & & 578 & $\begin{array}{l}\text { Cross } \\
\text { sectional }\end{array}$ \\
\hline MCQs test 2 mark & $64 \%$ & $62.9 \%$ & 10.53 & & 564 & $\begin{array}{l}\text { Cross } \\
\text { sectional }\end{array}$ \\
\hline MCQs test 3 mark & $58 \%$ & $57.5 \%$ & 12.45 & & 568 & $\begin{array}{l}\text { Cross } \\
\text { sectional }\end{array}$ \\
\hline Exam MCQs mark & $56 \%$ & $55.8 \%$ & 17.25 & & 578 & $\begin{array}{l}\text { Cross } \\
\text { sectional }\end{array}$ \\
\hline Exam written question mark & $40.8 \%$ & $42.1 \%$ & 21.47 & & 578 & $\begin{array}{l}\text { Cross } \\
\text { sectional }\end{array}$ \\
\hline $\begin{array}{l}\text { Connect online MCQ test } \\
\text { mark }\end{array}$ & $71.6 \%$ & $66.4 \%$ & 22.40 & & 576 & $\begin{array}{l}\text { Cross } \\
\text { sectional }\end{array}$ \\
\hline Female & $52.4 \%$ & & & & & $\begin{array}{l}\text { Cross } \\
\text { sectional }\end{array}$ \\
\hline B. Foundational bachelors & $18.2 \%$ & & & & & $\begin{array}{l}\text { Cross } \\
\text { sectional }\end{array}$ \\
\hline Bachelor of Science & $10.1 \%$ & & & & & $\begin{array}{l}\text { Cross } \\
\text { sectional }\end{array}$ \\
\hline Bachelor of Journalism & $2.1 \%$ & & & & & $\begin{array}{l}\text { Cross } \\
\text { sectional }\end{array}$ \\
\hline Bachelor of Arts & $16.0 \%$ & & & & & $\begin{array}{l}\text { Cross } \\
\text { sectional }\end{array}$ \\
\hline Bachelor of Commerce & $38.0 \%$ & & & & & $\begin{array}{l}\text { Cross } \\
\text { sectional }\end{array}$ \\
\hline Bachelor of Economics & $2.3 \%$ & & & & & $\begin{array}{l}\text { Cross } \\
\text { sectional } \\
\end{array}$ \\
\hline Bachelor of Social Science & $13.3 \%$ & & & & & $\begin{array}{l}\text { Cross } \\
\text { sectional }\end{array}$ \\
\hline
\end{tabular}

videoed supplement revising them explaining everything line upon line and precept upon precept. Yet, the performance was not impressive. All questions in the written component required a graph to be drawn if a candidate was to be successful. The average score for written questions was 42 per cent and the median, 41 per cent. This calls into question the pedagogic practice of graph-intensive learning and assessment processes in introductory economics, which I happened to be a culprit of.

To demonstrate Cohn and Cohn's (1994) claim that instructor-supplied graphs help 
struggling students reproduce correct graphs (though they were silent about interpretation), consider the scenario in Test 2 and the final examination, which required them to draw a demand and supply model if they were to answer all the relevant MCQs confidently and correctly.

Scenario JMK and answer questions 1.39-1.42. Suppose farmers start injecting cows with a hormone that causes them to give more milk. Then, the government announces that people who drink the milk from the hormone-treated cows will be healthier and live longer. [You may draw in the space below to help you answer the following questions. The drawing will NOT be graded.]

The most failed question in the scenario was Q1.42, which read as follows:

See Scenario JMK. The equilibrium price of milk

a. could increase or decrease.

b. will not change.

c. will decrease.

d. will increase

Table 2: Student Performance for Scenario JMK

\begin{tabular}{|c|c|c|c|c|}
\hline $\begin{array}{l}\text { Question in } \\
\text { test } 2\end{array}$ & $\begin{array}{l}\% \text { That failed } \\
\text { in test } 2 \\
\end{array}$ & $\begin{array}{l}\text { Question in } \\
\text { the exam }\end{array}$ & $\begin{array}{l}\text { \% That failed in } \\
\text { examination }\end{array}$ & $\begin{array}{c}\text { Difference of means test: } \mathrm{H}_{0} \text { : Mean } \\
\text { (test } 2)=\text { Mean (exam) }\end{array}$ \\
\hline 1.39 & 23.7 & 1.15 & 19 & \multirow{5}{*}{$\begin{array}{l}\mathrm{t}-\text { statistic }=2.61 \\
\text { one tailed } p \text {-value }=0.04 \\
\text { two tailed } p \text {-value }=0.08\end{array}$} \\
\hline 1.40 & 9.4 & 1.16 & 6.1 & \\
\hline 1.41 & 20.5 & 1.17 & 11.9 & \\
\hline 1.42 & 80.9 & 1.18 & 62.9 & \\
\hline$N$ & 575 & & 579 & \\
\hline
\end{tabular}

These findings (Table 2) significant at the 5 per cent level of significance agree with the hypothesis that instructor-supplied graphs help students draw better graphs. Notice that when the scenario came in test 2, it was the first time the students encountered it. The improvement in the examination performance (in Table 2, significant at the $5 \%$ test) can be explained by the students having read the memo, with detailed explanatory notes for each MCQ, that also provided a drawn graph for the scenario, with notes for each question $(1.39-1.42)$. This memo was given to students the day after they wrote test 2. A set of video clips explaining several MCQs, including the scenario was also uploaded to the course website three weeks before the examination. Students, notwithstanding, still struggled with question 1.18 (465 students failed in test 2 and 364 in the examination). Indeed, the number who failed Q1.42 (Q1.18) declined from 81 per cent to 63 per cent, something I would consider to be marginal (about 101 additional students got it correct in the exam). The hypothesis that instructor-supplied graphs can assist struggling students to draw accurate graphs (in the present case accurately interpret graphs) is 
confirmed (Cohn and Cohn 1994), but the number of students who still failed is worrisome to unreservedly support Cohn and Cohn's claim. It seems that instructor-supplied graphs are necessary but not sufficient for successful reproduction of graphs by students.

I consider the number of graph-based questions left unanswered to be a reflection of content difficulty. The graph-based MCQs were based on price legislation, tax incidence, indifference curves and production possibility frontiers. The indifference curve graph was the most challenging. The panel regression tests Cohn and Cohn's claim that instructor-provided graphs will help struggling students. Videoed graphs are probably the best instructor provided graphs with a lively element of the instructor speaking about the graph step by step as it is being visually constructed and then interpreting it. Table 3 reports the results of bootstrap linear regression models.

Table 3: Bootstrap Regressions Output for Number of Graph-Based MCQs Failed and Written Component Performance

\begin{tabular}{|c|c|c|c|c|c|}
\hline $\begin{array}{l}\text { \% Of graph based } \\
\text { MCQS failed }\end{array}$ & $\begin{array}{l}\text { Test } 2 \\
\text { MCQS } \\
\text { failed }\end{array}$ & $\begin{array}{l}\text { Test } 3 \\
\text { MCQS } \\
\text { failed }\end{array}$ & $\begin{array}{l}\text { Exam } \\
\text { MCQS } \\
\text { failed }\end{array}$ & $\begin{array}{l}\text { Exam MCQS failed } \\
\text { (by Economics } \\
\text { group onLY) }\end{array}$ & $\begin{array}{c}\text { Exam MCQS failed } \\
\text { (by Mathematics } \\
\text { group only) }\end{array}$ \\
\hline $\begin{array}{l}\% \text { of graph based MCQS } \\
\text { not answered }\end{array}$ & $\begin{array}{l}-0.634^{*} \\
(0.366)\end{array}$ & $\begin{array}{l}-0.766 \\
(0.685)\end{array}$ & $\begin{array}{l}-0.500^{\star \star \star} \\
(0.153)\end{array}$ & $\begin{array}{c}-0.410^{\star \star \star} \\
(0.106)\end{array}$ & $\begin{array}{c}-0.325^{\star \star \star} \\
(0.051)\end{array}$ \\
\hline Bachelor of Economics & $\begin{array}{l}-5.049 \\
(5.013)\end{array}$ & $\begin{array}{l}-2.554 \\
(6.887)\end{array}$ & $\begin{array}{l}10.281^{*} \\
(6.166)\end{array}$ & $\begin{array}{c}6.299 \\
(6.565)\end{array}$ & $\begin{array}{c}4.791 \\
(4.045)\end{array}$ \\
\hline Bachelor of Journalism & $\begin{array}{l}-8.789^{\star \star \star} \\
(3.257)\end{array}$ & $\begin{array}{l}16.571^{*} \\
(9.048)\end{array}$ & $\begin{array}{c}35.806^{\star \star \star} \\
(9.058)\end{array}$ & $\begin{array}{c}29.402^{\star \star \star} \\
(5.178)\end{array}$ & $\begin{array}{c}4.830 \\
(12.069)\end{array}$ \\
\hline Bachelor of Science & $\begin{array}{l}1.170 \\
(6.970)\end{array}$ & $\begin{array}{c}2.169 \\
(7.498)\end{array}$ & $\begin{array}{c}18.954^{\star \star} \\
(9.163)\end{array}$ & $\begin{array}{c}3.950 \\
(10.652)\end{array}$ & $\begin{array}{l}1.237 \\
(3.200)\end{array}$ \\
\hline Bachelor of Commerce & $\begin{array}{l}-4.271 \\
(3.467)\end{array}$ & $\begin{array}{l}-0.157 \\
(4.997)\end{array}$ & $\begin{array}{c}2.526 \\
(4.274)\end{array}$ & $\begin{array}{l}-1.791 \\
(4.258)\end{array}$ & $\begin{array}{l}-2.408 \\
(1.785)\end{array}$ \\
\hline $\begin{array}{l}\text { Bachelor of Social } \\
\text { Science }\end{array}$ & $\begin{array}{l}2.414 \\
(4.745)\end{array}$ & $\begin{array}{c}1.760 \\
(5.310)\end{array}$ & $\begin{array}{c}5.973 \\
(5.591)\end{array}$ & $\begin{array}{l}2.330 \\
(5.344)\end{array}$ & $\begin{array}{c}0.470 \\
(3.163)\end{array}$ \\
\hline Bachelor of Arts & $\begin{array}{l}-2.620 \\
(6.157) \\
\end{array}$ & $\begin{array}{c}-16.617^{\star \star \star} \\
(5.279)\end{array}$ & $\begin{array}{c}8.232 \\
(5.858) \\
\end{array}$ & $\begin{array}{c}3.217 \\
(3.949) \\
\end{array}$ & $\begin{array}{l}1.686 \\
(2.913) \\
\end{array}$ \\
\hline Female & $\begin{array}{l}1.723 \\
(2.980)\end{array}$ & $\begin{array}{c}6.037 \\
(5.039)\end{array}$ & $\begin{array}{l}0.385 \\
(3.412)\end{array}$ & $\begin{array}{l}5.942^{\star \star} \\
(2.893)\end{array}$ & $\begin{array}{c}0.934 \\
(1.674)\end{array}$ \\
\hline Matric economics mark & $\begin{array}{l}-0.256^{\star \star} \\
(.126)\end{array}$ & $\begin{array}{c}0.113 \\
(0.208)\end{array}$ & $\begin{array}{l}-0.283^{\star} \\
(0.150)\end{array}$ & $\begin{array}{l}-0.307^{\star} \\
(0.161)\end{array}$ & \\
\hline Matric mathematics mark & $\begin{array}{c}-.215 \\
(0.159) \\
\end{array}$ & $\begin{array}{l}-0.236 \\
(0.177) \\
\end{array}$ & $\begin{array}{l}-0.619^{\star \star \star} \\
(0.168)\end{array}$ & & $\begin{array}{l}-0.294^{\star \star \star} \\
(0.096)\end{array}$ \\
\hline Matric points & $\begin{array}{l}-0.147 \\
(0.415)\end{array}$ & $\begin{array}{l}-0.892 \\
(0.464)\end{array}$ & $\begin{array}{c}0.607 \\
(0.436)\end{array}$ & $\begin{array}{l}-0.195 \\
(0.488)\end{array}$ & $\begin{array}{l}-0.169 \\
(0.216)\end{array}$ \\
\hline $\begin{array}{l}\text { Connect online MCQ } \\
\text { mark }\end{array}$ & $\begin{array}{l}-0.139 \star \star \star \star \\
(0.036)\end{array}$ & $\begin{array}{l}-0.397^{\star \star \star} \\
(0.098)\end{array}$ & $\begin{array}{l}-0.241^{* \star *} \\
(0.080)\end{array}$ & $\begin{array}{l}-0.308^{\star \star \star *} \\
(0.065)\end{array}$ & $\begin{array}{c}-0.245^{\star \star \star} \\
(.031)\end{array}$ \\
\hline Constant & $\begin{array}{c}79.356^{\star \star \star} \\
(9.158)\end{array}$ & $\begin{array}{c}115.2 \\
(14.367)\end{array}$ & $\begin{array}{l}74.880^{\star \star \star} \\
(15.559)\end{array}$ & $\begin{array}{l}78.286^{\star \star \star} \\
(13.694)\end{array}$ & $\begin{array}{c}74.427^{\star \star \star} \\
(6.754)\end{array}$ \\
\hline Observations & 112 & 112 & 116 & 149 & 480 \\
\hline Replications & 30 & 30 & 25 & 45 & 50 \\
\hline Wald $\mathrm{Chi}^{2}(12)$ & 156.94 & 113.72 & 192.31 & 126.62 & $\mathrm{Chi}^{2}(11) 160.53$ \\
\hline $\mathrm{P}\left(\mathrm{Chi}^{2}(12)>\mathrm{Chi}^{2}, 0.05\right)$ & 0.000 & 0.000 & 0.000 & 0.000 & 0.000 \\
\hline $\mathrm{R}^{2}$ & 0.293 & 0.289 & 0.314 & 0.280 & 0.176 \\
\hline Adjusted $\mathrm{R}^{2}$ & 0.208 & 0.203 & 0.234 & 0.222 & 0.157 \\
\hline Root MSE & 12.188 & 18.779 & 15.913 & 17.052 & 16.960 \\
\hline
\end{tabular}

${ }^{a *} p<0.10 ;{ }^{* \star} p<0.05 ;{ }^{\star \star \star} p<0.01$

As the percentage of graph-based MCQs that were not answered increased, the percentage of graph-based MCQs that were failed declined by between 0.3 and 0.6 percentage points, 
somehow a weak effect although very significant (Table 3). Surprisingly, bachelor of economics students failed 10 per cent more graph-based MCQs than foundational bachelors students, something that suggests the effect of complacence. Bachelor of Journalism students failed 9 per cent less graph-based MCQs than foundation students in test 2, but did comparatively worse in test 3 (failing 17\% more), in the examination (failing 36\% more) and in the subsample for economics (failing 29\% more). Bachelor of Science students failed 19 per cent more graph-based MCQs than foundational students in the examination. Contrary, to my expectations, Bachelor of Arts students did better than foundational students, failing 17 per cent less graph-based MCQs in test 3.

Female students did worse than males in the subsample for economics, failing 6 per cent more questions in the examination, a result that suggests gender bias in graph-based assessments. As expected, a 1 per cent point increase in matric economics marks had the effect of reducing the number of graph-based MCQs failed by about 0.3 per cent points across all assessments (Table 3). A 1 per cent increase in matric maths score reduced the percentage of graph-based MCQs failed by 0.6 per cent points in the exam and 0.3 per cent points in the subsample for mathematics. Consistently, a 1 per cent point increase in a student's online (Connect) MCQ performance reduced the proportion of graph-based MCQs failed by between 0.1 per cent and 0.4 per cent points. Although matric economics and mathematics as well as the Connect MCQ performance have the theoretically expected signs, their marginal contributions are economically small. They didn't give students a huge performance premium over those who had no, or had miserable, matric economics, maths and Connect performance records.

Experimental designs to evaluate the effects of graph dominated pedagogy and curriculum in economics acknowledge that all they can assess is short term learning (Cohn et al. 2001; Cohn et al. 2004). However, with a panel set such as the one used in this study (Table 4), the intellectual development of the learner can be evaluated temporally. In addition, the same learners are both the control group (at the start of the course) and treatment group (after some time of learning), hence the information revealed by the panel regression results might be more insightful.

Table 4 shows that the fixed effects model was preferred to the random effects model in the present circumstances. The Hausman specification test statistic was significant at the 5 per cent level of significance, implying that the coefficients in the random effects model were systematically different from those in the fixed effects model. A 1 per cent point increase in the number of unanswered graph-based MCQs led to a 0.6 per cent points decrease in the number of graph-based MCQs failed, an effect quite close to the cross sectional estimate. Students failed 
14 per cent less of graph-based MCQs when there was negative marking than they did without negative marking. However, this does not mean negative marking performed miracles of making students get correct answers. Rather its effect, which is an epistemically undesirable one, implies that students answered fewer graph-based questions for fear of the penalty.

Table 4: Panel Regression for Failed Graph Based MCQs

\begin{tabular}{|c|c|c|}
\hline$\%$ Of graph based MCQS failed & $\begin{array}{l}\text { Fixed effects } \\
\text { estimates }\end{array}$ & $\begin{array}{l}\text { Random effects } \\
\text { GLS estimates }\end{array}$ \\
\hline$\%$ of graph based MCQs not answered & $\begin{array}{l}-0.552^{\star \star \star} \\
(0.123)\end{array}$ & $\begin{array}{l}-0.452^{\star * \star} \\
(0.112)\end{array}$ \\
\hline Negative marking dummy & $\begin{array}{c}-14.331^{\star \star *} \\
(0.954)\end{array}$ & $\begin{array}{c}-14.733^{\star \star \star} \\
(0.937)\end{array}$ \\
\hline Supplementary video learning materials dummy & $\begin{array}{l}14.088^{\star \star \star} \\
(0.840)\end{array}$ & $\begin{array}{c}14.194^{\star \star \star} \\
(0.839)\end{array}$ \\
\hline $\begin{array}{l}\text { Negative marking dummy* video learning materials } \\
\text { dummy* } \% \text { of graph based MCQs not answered }\end{array}$ & $\begin{array}{l}0.1439 \\
(0.130)\end{array}$ & $\begin{array}{c}0.109 \\
(0.121)\end{array}$ \\
\hline Constant & $\begin{array}{l}36.599 \star \star \star \\
(0.612)\end{array}$ & $\begin{array}{c}36.460 * \star \star \\
(0.775)\end{array}$ \\
\hline Sigma_u & 14.213 & 11.448 \\
\hline Sigma_e & 13.986 & 13.986 \\
\hline Rho & 0.508 & 0.401 \\
\hline Observations & 1703 & 1703 \\
\hline Number of groups & 578 & 578 \\
\hline $\mathrm{F}(4,1121)$ & $137.93(p=0.00)$ & \\
\hline Wald $\mathrm{Chi}^{2}(4)$ & & $543.23(p=0.00)$ \\
\hline $\mathrm{R}^{2}$ within & 0.330 & 0.329 \\
\hline $\mathrm{R}^{2}$ between & 0.002 & 0.002 \\
\hline $\mathrm{R}^{2}$ overall & 0.156 & 0.158 \\
\hline Corr(u_i, xb) & -0.0375 & 0 (assumed) \\
\hline $\begin{array}{l}\text { Hausman specification test } \\
\text { HO: difference between coefficients in the fixed effects and } \\
\text { random effects regressions is not systematic }\end{array}$ & \multicolumn{2}{|c|}{$\begin{array}{c}\text { Chi }^{2}{ }_{(4)}=10.98 \\
\mathrm{P}\left(\mathrm{Chi}^{2}{ }_{(4)}>\mathrm{Chi}^{2}{ }_{\text {critical }}\right)=0.027\end{array}$} \\
\hline
\end{tabular}

${ }^{a *} p<0.10 ;{ }^{\star \star} p<0.05 ;{ }^{* \star \star} p<0.01$

Quite surprisingly, students failed 14 per cent more questions with videoed supplementary learning materials than tests they wrote without videoed supplementary learning material. The positive coefficient on the dummy for video supplementary learning materials is contrary to expectations and, on the main, contradictory to Cohn and her co-authors' claim that instructorsupplied graphs will help students reproduce (and perhaps interpret) graphs correctly. Upon reflection, the puzzling positive sign can be explained. Croker et al. $(2010,2)$ postulated the procrastination hypothesis, which states that video and audio learning technologies may fail to compel ‘immediate engagement and (deep) learning' (emphasis mine) because students simply download the materials, store them and postpone usage to a later date, which they will eventually do superficially under pressure to over extensive ground. For example, if students are given correct graphs, but they skim through them the night before the examination, one would not expect miracles. They will be enticed into answering all graph-based questions 
thinking that they understand them, when they, in fact, have superficial understanding. One candidate's parent sent me an email after sending one to the Department of Economics asking for access to the examination script of her daughter. She said:

I sent an email to the Economics department about my daughter ... who was shocked to receive her results. She says she does not understand how she could have done so poorly ... My daughter ... would like to come and discuss her exam results as she says she cannot believe that she could have done so poorly ... (Email from concerned parent 2016, emphasis mine).

When I went through the script with her, the memo in her hands, she exclaimed, 'O gosh! I thought I got these things right. Obviously, something was wrong with my reading'. I pointed out to her that all these questions (both written and MCQ components) were discussed in the videos. She said, ‘I know. I watched them. That's why I couldn’t belief that I failed because I thought I was on top of the exam.' As such, instructor-provided supplementary graphs with detailed step by step explanation are only a necessary condition, but not sufficient to guarantee successful/correct interpretation and reproduction of graphs by learners. The supplementary materials might deceive those who use surface and strategic learning approaches (Biggs 1999; Mann 2001) into believing that they understand issues, resulting in them answering more questions than they would ordinarily answer in the presence of negative marking. The video effect is adverse in such circumstances.

The results in Table 4 lead to three important conclusions. Firstly, the inverse relationship between the proportion of graph-based questions not answered and proportion of graph based questions failed suggests that students' dominant strategy is to increase the number of unanswered graph-based questions, especially in the context of negative marking. There is nothing praiseworthy in leaving so many questions unanswered, some of which one would have made a correct intuitive guess if they were not afraid of negative marking. Secondly, the coefficient of the negative marking dummy conveys adverse information about the role of negative marking. Notice that in Table 1 it is the examination that has the highest percentage of non-attempted graph-based MCQs (a mean of $8 \%$ of the questions), yet for test 2 and 3, which had no negative marking, the proportion of graph based questions that were not answered was roughly 1 per cent. Thirdly, instructor supplied supplementary graph based study resources (videoed supplementary study and revision materials) do not necessarily translate into improved performance (correct reproduction, interpretation and application). There are several intervening factors that have to be interrogated. Cohn and Cohn's (1994) hypothesis that instructor-supplied graphs can help struggling students is confuted by the present results.

These broad conclusions indict many economics textbooks and teachers that habitually 
use the graphs to verbal mode of instruction. A no graphs curriculum of economics is impossible however, for the simple reason that there are aspects such as Q1.42 above that require a visual representation to be able to perceive all the various combinations that emerge due to a simultaneous shift of demand and supply. These findings suggest that teachers of economics have to rethink the use of graphs in their teaching and that they should use only graphs with exceptional pedagogical value.

\section{EXHIBITS FROM STUDENT DRAWN GRAPHS}

In the examination, there were six questions, three of which had to be answered. The three questions were based on 'markets and government intervention', 'production and costs' and 'market structures'. In the 'markets and government intervention' section, one question tested the student's understanding of the revenue and other distributional implications of increasing excise taxes on alcohol and cigarettes in the 2016 National Budget Speech for South Africa. The other question focused on the influence of increasing excise tax rates on consumer behaviour given empirical estimates of income and price elasticities of demand for cigarettes and commercial sorghum beer. Cigarettes were a normal good (a good who demand increases/decreases with disposable income increase/decrease respectively), but commercial sorghum beer was a giffen good (a good whose quantity demanded increases/decreases with price increase/decrease respectively). In an attempt to illustrate tax incidence and the size of government revenue collected from imposing an excise tax, many unusual and incorrect graphs were drawn, a typical case being Figure 1.

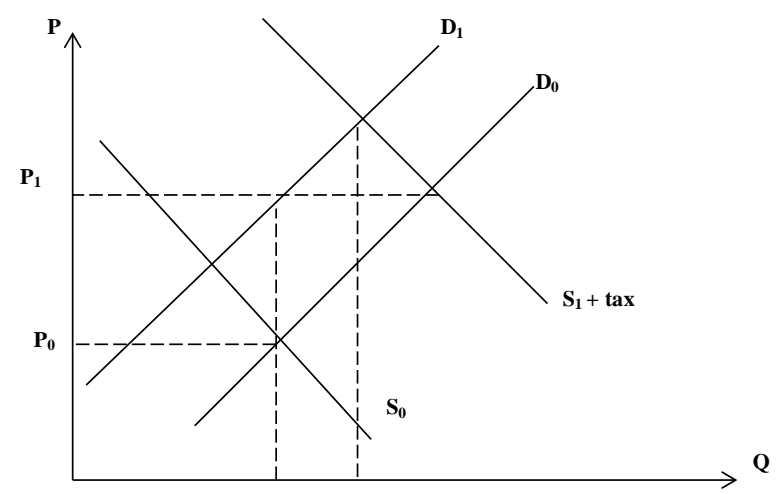

Figure 1: Demonstrating tax incidence and government revenue

Notice that the learner here drew a downward sloping supply curve and an upward sloping demand curve. This type of error has been encountered in public finance, environmental 
economics and mathematic economics to the extent that one external examiner for the public finance in the 2015 examination reported that 'a lot of students seem to struggle with graphs'. These were third years in economics that, like the first year student in Figure 1, were drawing downward sloping supply curves and upward sloping demand curves, which are complete violations of economic fundamentals.

Figure 2 demonstrates 3 typical answers I encountered in hundreds of scripts. What is obvious from these graphs is that some learners had no clue how indifference curves were used. Supply curves and demand curves (presumably interchanged with budget lines) were combined with indifference curves to discuss changes in consumer behaviour induced by the excise tax. The price-quantity space was used to analyse consumer choice, which should be set forth in a product-product space. The bottom graph in Figure 2 suggests that the candidate had no idea of what consumer equilibrium is; hence many indifference curves were drawn to explain nothing.
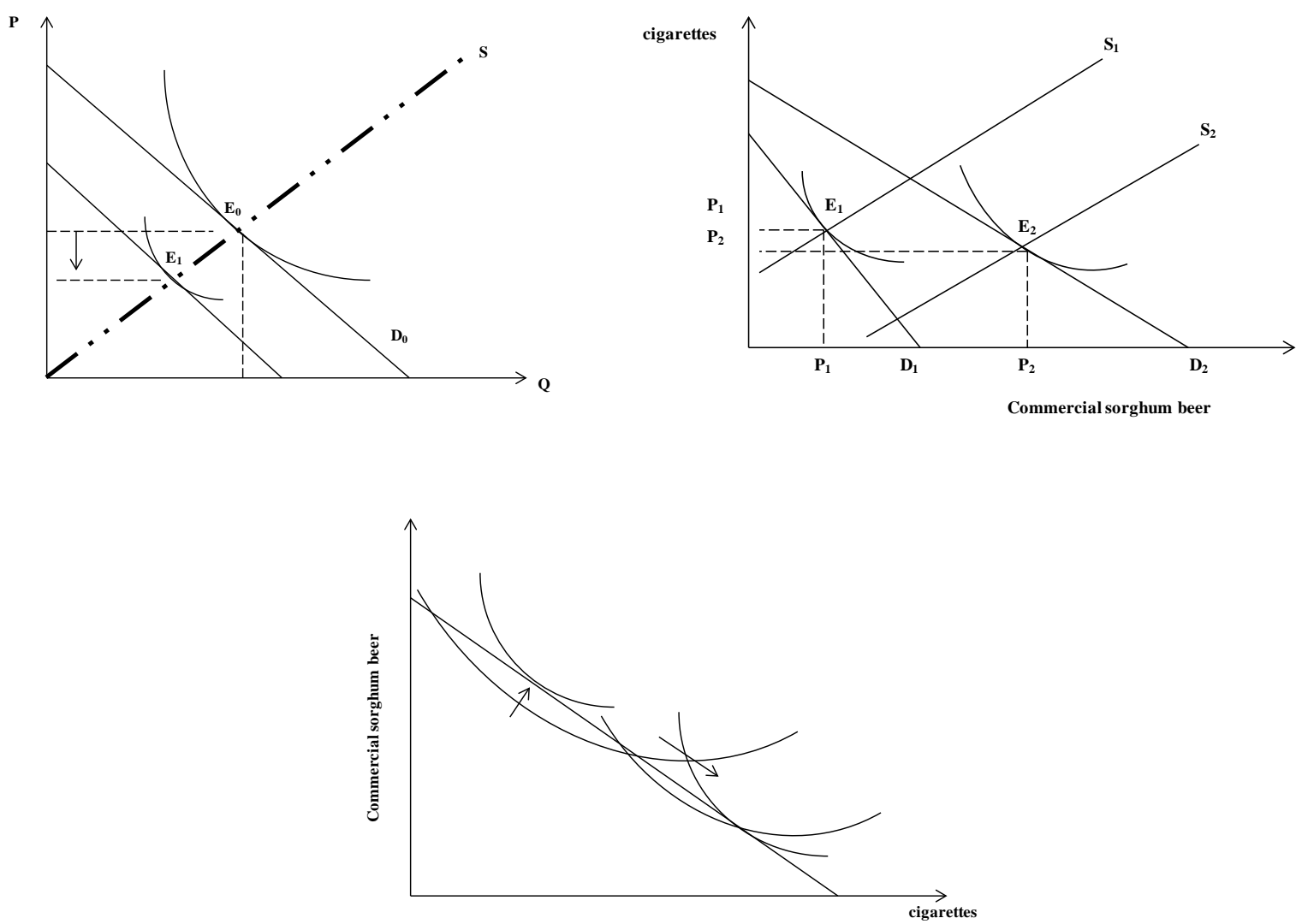

Figure 2: Changes in consumer behaviour due to the increase in the excise tax rate

The problem of incomprehension becomes even graver as one move to the theory of production and costs. The law of diminishing marginal returns seems to never have been understood. In Figure 3, in the top left panel, one sees a clear confusion in the candidate's thought process. Marginal cost is greater than total cost and average cost is initially greater than total cost and 
eventually less than total cost! In the bottom left panel, the relationships between total cost and variable costs is confused for the relationship between total product and average product! Even the average product increases indefinitely, which is unheard of in economic theory. In the top right panel of Figure 3, the total product is drawn as though it was the marginal cost curve and the average product is drawn as though it was the average cost curve! In the bottom right panel, the total product curve is drawn as though it was the average fixed cost curve! These four graphs, with some variation, were common in the examination scripts.

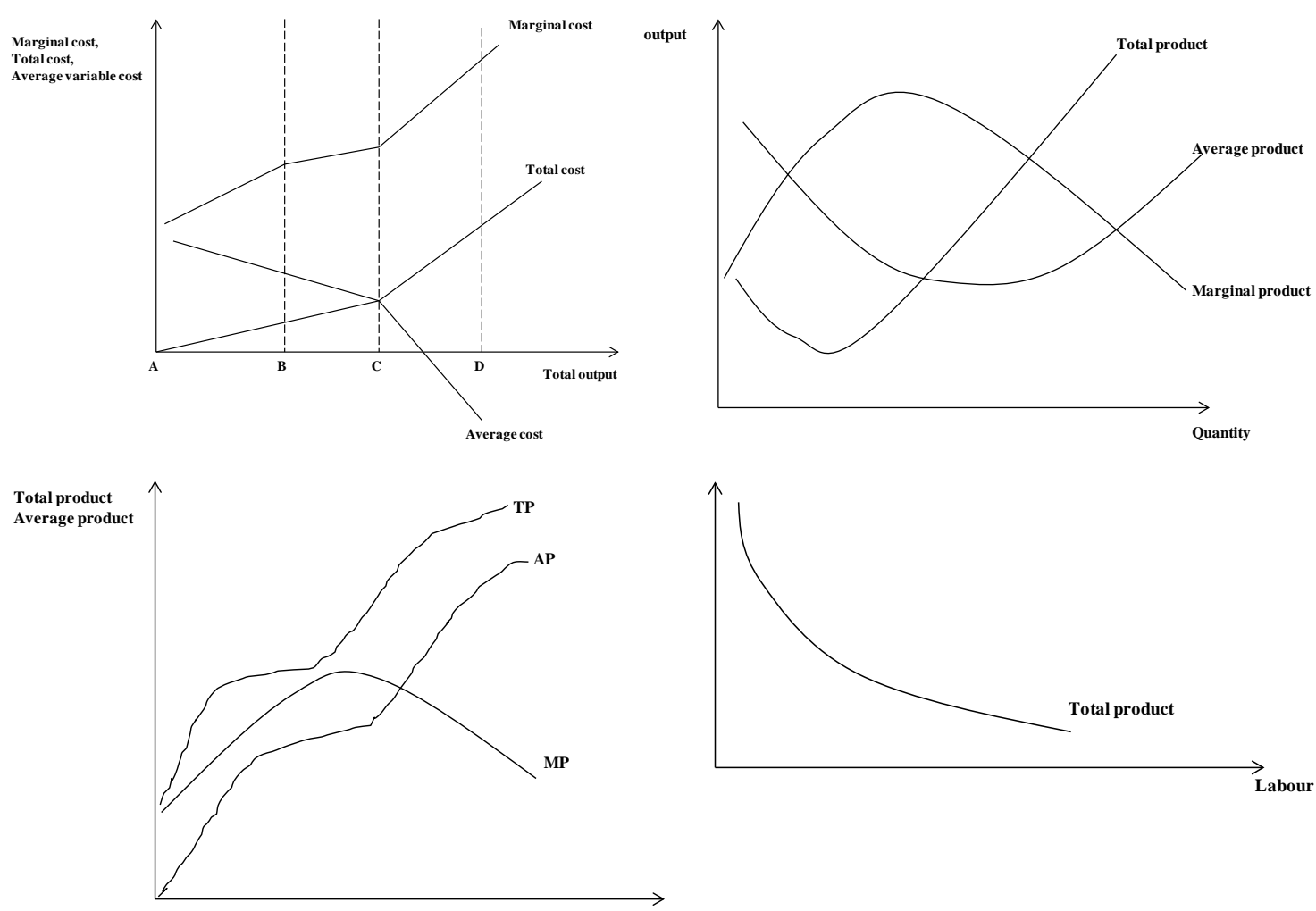

Figure 3: Relationships between product curves and cost curves

Lastly, Figure 4 focused on evaluating the implications of monopoly on efficiency and welfare using concepts such as economic profit, consumer surplus, producer surplus and so forth. Figure 4 reveals several problems. The candidate seemed ignorant of what consumer and producer surplus were. This was clear from the positioning of the shaded triangular areas. For this candidate, total surplus was the area bounded by the average variable cost and the marginal cost under perfect competition (left panel, Figure 4) and area bounded by average cost and marginal cost under monopoly (right panel, Figure 4). In the left panel, no demand curve was shown (the average revenue curve). There was, of course, some idea in the answer that where normal profits are earned, marginal cost and average cost are equal, but the location of the surplus was entirely wrong. The role of demand and supply was not understood nor was the fact that a monopolist 
has no supply curve. There was no evidence that the student understood the role of the profit maximizing rule in the identification of the consumer surplus under the monopoly market structure.
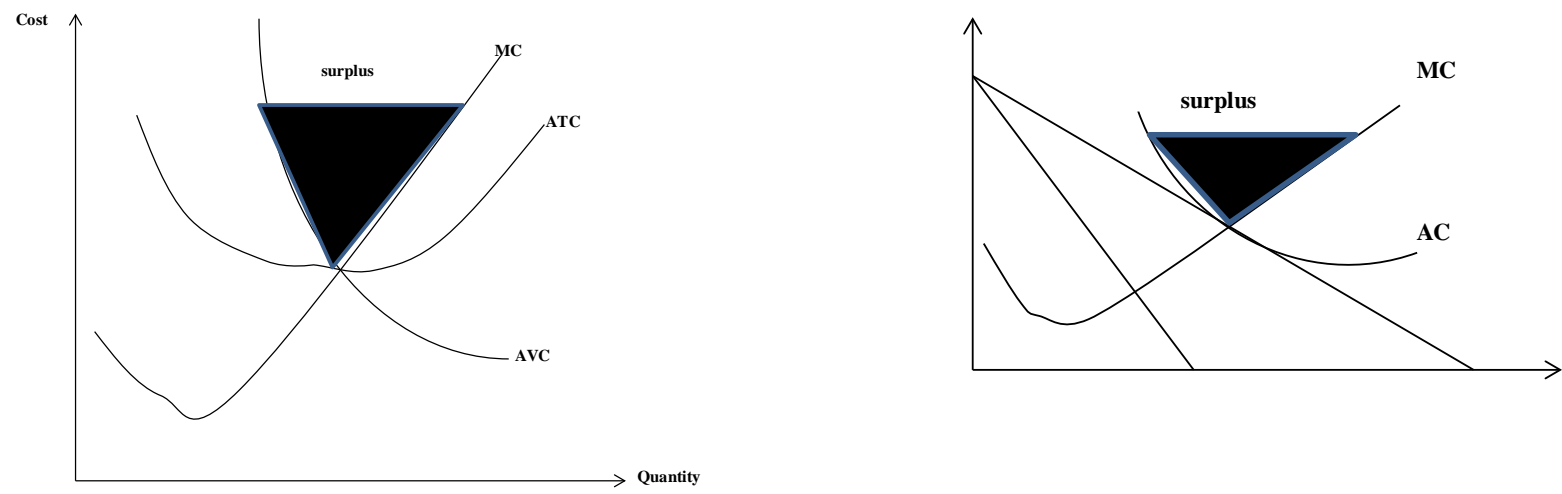

Figure 4: Comparison of efficiency and welfare implications of monopoly relative to perfect competition

\section{DISCUSSION}

Taken together, these pictorial, regression and descriptive results suggest that the use of graphs in the teaching and assessment of economics needs re-evaluation. The dominance of graphs in the pedagogy of economists needs to be questioned critically and alternative approaches explored. This is not to say graphs should be eliminated from pedagogic practices in economics but that a judicious selection of graphs that serve the most valuable pedagogic functions be engendered. The results confirm some conclusions that had remained hypothetical postulations. It is now evident that students cannot reproduce correct graphs. It is evident that supply of supplementary learning resources that explain things step by step helps some students to draw good graphs, but not many of them. It is only a necessary but not a sufficient condition for accurate reproduction.

In recent years other teachers of economics have moved away from too much graph dominated pedagogies and now use a variety of approaches such as music, novels, newspapers, games, experiments, and simulations to teach introductory economics (Hall and Lawson 2008; Lawson, Hall and Mateer 2008; Medcalfe 2010). The graph dominated teaching style is consistent with the 'chalk and talk' tradition in economics that all the national surveys carried out by Becker and his co-authors found to be a steady state feature in the teaching of economics.

Deeper student engagement begins with generating student interest in economics, then strategically manipulating that nascent interest to ground students in economic theory. Such pedagogies are student-centred and are driven by learners' intellectual interests rather than the instructor's disciplinary traditions and tastes. Such pedagogic practices are consistent with 
Parker's (2003) sparky curriculum. A curriculum that is co-produced, co-shaped, co-reviewed, co-implemented and co-delivered with the students, a curriculum which is transformational in effect.

In terms of economics curriculum practices that are relevant to an epistemically diverse learner community, newer approaches that move away from canonical economic pedagogic practices provide students with four sets of knowledge: propositional knowledge, applied knowledge, experiential knowledge and meta-knowledge (metacognitive and epistemically cognitive skills) (Luckett 2001). This dynamic curriculum is relevant for first timers in economics and even beyond. When students' lives are occupied with memorizing confusing graphs, they learn less, understand much less and retain deplorably much less.

\section{PEDAGOGIC AND CURRICULUM IMPLICATIONS}

The findings suggest that several types of bias have to be eliminated ranging from gender to epistemological biases by engendering a curriculum that accommodates epistemic diversity. That diversity can be accommodated by eliminating constraints to access to knowledge such as inverted graphic and algebraic representations of economic theory. Epistemic scaffolding is still needed but probably the type that decodes the discipline. The results suggest that some timehonoured practices such as negative marking have to be re-evaluated.

\section{CONCLUSION}

The article set out to assess the role of graph dominated curriculum practices in economics and the extent to which such practices engender student learning and whether instructor supplied graphic material improved student access to economic theory. The results suggested that graphs did not facilitate learning and instructor-supplied graphs were necessary but not sufficient in eliminating the epistemic gap: both MCQ-based data, which reveals interpretive skills of students, and written questions-based data, which reveals ability to apply graphs converged on the same conclusion that graphs caused confusion for many students. As such, it seems plausible to recommend that practices such as negative marking, graph-intensive examination and teaching practices be seriously reflected upon. This is even more imperative given the lowering of matric mathematic standards by the Department of Education in South Africa. A call for teaching the non-visually impaired as if they were visually impaired in the absence of learning material in Braille is a logical recommendation from these results. It is a call to student-centred pedagogic approaches and to experiment with many alternative strategies that engender an epistemically diverse and sexier economics curriculum. 


\section{REFERENCES}

Becker, W. E. and M. Watts. 1996. Chalk and talk: A national survey on teaching undergraduate economics. The American Economic Review 86(2): 448-453.

Becker, W. E. 2001. How to make economics the sexy social science. Chronicle of Higher Education 48(15).

Becker, W. E. 2003. How to make economics the sexy social science (From Chronicle of Higher Education). Southern Economic Journal 70(1): 195-198.

Biggs, J. 1999. What the student does: Teaching for enhanced learning. Higher Education Research \& Development 18(1): 57-75.

Cohn, E. and S. Cohn. 1994. Graphs and learning in principles of economics. The American Economic Review 84(2): 197-200.

Cohn, E., S. Cohn, D. C. Balch and J. Bradley Jr. 2001. Do graphs promote learning in principles of economics? Journal of Economic Education Fall: 299-310.

Cohn, E., S. Cohn, D. C. Balch and J. Bradley Jr. c.2002. Student attitudes about graphs and their relation to performance in principles of economics. Joint Statistical Meetings - Business \& Economic Statistics Section: 604-609.

Cohn, E., S. Cohn, D. C. Balch and J. Bradley Jr. 2004. The relation between student attitudes toward graphs and performance in economics. The American Economist 48(2): 41-52.

Coyle, D. 2012. Economics education after the crisis: Are graduate economists fit for purpose? http://www.res.org.uk/view/article5Apr12Correspondence.html (Accessed 29 May 2016).

Coyle, D. 2014. The mainstream economics curriculum needs an overhaul. http://voxeu.org/ article/mainstreameconomicscurriculumneedsoverhaul (Accessed 29 May 2016).

Croker, K., H. Andersson, D. Lush, R. Prince and S. Gomez. 2010. Enhancing the student experience of laboratory practicals through digital video guides. Bioscience Education 16(1): 1-13.

Hall, J. and R. Lawson. 2008. Using music to teach microeconomics. Perspectives in Economic Education Research 4(1): 23-36.

Harter, C. L., W. E. Becker and M. Watts. 1999. Who teaches with more than chalk and talk? Eastern Economic Journal 25(3): 343-356.

Inman, P. 2013a. Economics students aim to tear up free-market syllabus. The Guardian. https://www.theguardian.com/business/2013/oct/24/studentspostcrasheconomics [accessed 29 May 2016].

Inman, P. 2013b. University economics teaching to be overhauled. The Guardian. Available: https://www.theguardian.com/education/2013/nov/11/universityeconomicsteachingoverhaul (Accessed 29 May 2016.

Janse van Rensburg, J., C. R. McConnell and S. L. Bruce. 2015. Economics Southern African. 2nd Edition. Maidenhead: McGraw-Hill Higher Education.

Kourilsky, M. and M. C. Wittrock. 1987. Verbal and graphical strategies in the teaching of economics. Teaching \& Teacher Education 3(1): 1-12

Lawson, R., J. Hall and G. D. Mateer. 2008. From Abba to Zeppelin, Led: Using music to teach economics. The Journal of Economic Education 39(1): 107.

Luckett, K. 2001. A proposal for an epistemically diverse curriculum for South African Higher Education in the $21^{\text {st }}$ Century. South African Journal of Higher Education 15(2): 49-61.

Mankiw, G. N. 1997. Principles of microeconomics. Fort Worth: Dryden.

Mann, S. J. 2001. Alternative perspectives on the student experience: alienation and engagement. Studies in Higher Education 26(1): 7-19.

Medcalfe, S. 2010. The relationship between music and student enjoyment of economics class: How to 
compete with grand theft auto, crack and chlamydia! Journal of Economics and Economic Education Research 11(3): 39-46.

New American Standard Bible. 2009. Peabody: Hendrickson Bibles.

Ojo, E. and L. Jeannin. 2016. The way economics is taught needs an overhaul: A South African case study. The Conversation.

Parker, J. 2003. Reconceptualising the curriculum: From commodification to transformation. Teaching in Higher Education 8(4): 529-543.

Parkin, M., G. Antrobus, P. Baur, J. Bruce-Brand, M. Kohler, L. Neethling, B. Rhodes, A. Saayman, V. Schöer, D. Scholtz, K. Thompson and E. J. van der Merwe. 2013. Economics: Global and Southern African perspectives. Cape Town: Pearson Education.

Snowball, J. D. 2014. Using interactive content and online activities to accommodate diversity in a large first year class. Higher Education 67: 823-838.

The Economist. 2013. Post-crisis economics: Keynes’s new heirs: Britain leads a global push to rethink the way economics is taught.

University of Manchester Post-Crash Economics Society. 2014. Economics, education and unlearning: Economics education at the University of Manchester.

Watts, M. and W. E. Becker. 2008. A little more than chalk and talk: Results from a third national survey of teaching methods in undergraduate economics courses. The Journal of Economic Education 39(3): 273-286.

Wooldridge, J. 2002. Econometric analysis of cross section and panel data. MIT Press.

Zetland, D., C. Russo and N. Yavapolkul. 2010. Teaching economic principles: Algebra, graph or both? The American Economist 55(1): 123-131. 